\title{
BUILDING CULTURAL COMPETENCE OF FUTURE ECONOMISTS BY INTRODUCING INTERACTIVE TEACHING METHODS
}

\section{Varnavska I. V.}

\section{INTRODUCTION}

In the conditions of integration and globalization of Ukraine, the professional training of future specialists of economics in educational institutions of all levels acquires professional training. According to the Concept for development of the digital economy and society for 2018-2020 in Ukraine, the main tasks at all levels of higher economic education need to be revised not only in terms of developing digital competences of future specialists - the ability to use the latest technologies in further professional activities, but also the formation of their key competences, that will ensure continuing personal and professional growth, their effective social adaptation, high-quality professional development and life activities in general, competitiveness in the world labour market.

One of the key competences, the formation of which, under the basic normative documents (the Laws of Ukraine "On Education", "On Higher Education", Resolution of the Cabinet of Ministers "On approval of the National Qualifications Framework", Recommendations of the European Parliament and the Council of Europe on the Formation of Key Competences for Lifelong Learning), is an educational priority, a certain cultural competence as the ability of a person to reflect on his/her activities, effectively manage time and social information, work with others in a constructive direction.

Consequently, the problem of developing the cultural competence of future economists in the process of training becomes particularly acute, because it determines the ability of a specialist to work in a team, interact effectively in a digital society, achieve the goals set, make decisions, design their own social, personal and professional growth, respond constructively to stress, etc.

Cultural competence is an integral quality of a person, which manifests itself in the general ability and capacity of a person for a variety of activities, socially orientates a person towards independent and successful life activities. The assessment of cultural competence is based on a set of pedagogical approaches - normative, competence-based, personal, technological.

The principles of cultural competence assessment are integrity, dynamism, continuity, informativeness, cyclicality, consistency, effectiveness. The main directions of competence assessment are activities for the identification of a) 
competences related to an individual as a personality, subject of activity and communication; b) competences relating to the social interaction of a person and social environment; c) competences relating to a person activity. The assessment technology includes some components: a goal that takes into account a large number of indicators of the assessed object; an output object (cultural competence), described through a set of defined characteristics; a sequence of assessment operations described in the form of a flow chart; assessment tools (incoming, intermediate, final diagnostics); feedback.

\section{Innovative components of building cultural competence of future economists}

The formation of the cultural competence of future economists is complicated when applying traditional forms for educational institutions and methods of training, which are mainly focused on knowledge, without context, which are directed to passive memorization of the material, and do not cause any emotions. Results of analysis of scientific researches on the problem of professional training of future specialists in educational institutions in general (Pometun O.I. ${ }^{1}$, Komar O.A. ${ }^{2}$, etc.) and the formation of the social competence of a personality enables that the methods of successful formation of cultural competence of future economists in the learning process should meet the following modern requirements, as to be:

- competence-based in nature, i.e. meeting all the principles of the competence-based approach in education;

- effective in terms of the set educational objectives, i.e. those that ensure the achievement of program learning outcomes defined by the standards of higher education speciality and institution of higher education;

- contextual, professionally-oriented, reflecting the realities of future economic activities;

- developing, such as activating self-development and self-organization processes of an applicant, his learning and professional motivation and reflection;

- complex, such as those, which are aimed at future specialists' gaining necessary professional knowledge and skills, as well as acquiring professional experience;

- universal, such that can be used in the process of professional training of students of different economic specialities.

\footnotetext{
${ }^{1}$ Pometun O.I., Pirozhenko, L.V. (2002) Interactive Learning Technologies: Theory, Practice, Experience. Kyiv : NAPN, 2002.

${ }^{2}$ Komar O.A. Interactive technologies in Higher Studying Institutions. URL: http://dspace.udpu.org.ua:8080/jspui/bitstream/6789/375/1/interaktuvni_tehn_vnz.pdf.
} 
Unfortunately, social orientation as a modern requirement for the learning process is not traceable.

Among such innovative (contrary to traditional) methods that correspond to the above-mentioned requirements, in our opinion, interactive teaching methods occupy a special place.

Such training effectively contributes to the formation of professional values, skills and abilities, creates an atmosphere of cooperation, interaction, allows applicants to master socio-professional norms and models of social interaction.

The purpose of using teaching methods in the training of applicants is to provide a comfortable psychological and pedagogical environment that contributes to better and more effective preparation for future activities, the formation of skills necessary and sufficient for solving professional problems, the development of critical thinking and the formation of a personality.

According to A. Verbitsky ${ }^{3}$, interactive forms and methods can stimulate students' interest in learning and knowledge, since they help to solve some tasks that are not always possible during traditional training. This concerns the formation of not only cognitive, but also professional motives and interests; the upbringing of systemic critical thinking of specialists, which consists in a holistic sense, firstly, nature and society, and, secondly, more important, itself, its place in the world; to give a holistic idea of professional activity and its separate fragments; to teach collective mental and practical work, to develop the ability and skills of social interaction and communication, and supported decision-making, etc.

Based on the research of L.V. Pirozhenko, O.I. Pometun ${ }^{4}$, all teaching methods used in the process of forming the social competence of future economists are divided into the following types: 1) by the number of participants in direct interaction: cooperative (group, paired) and frontal; 2) by the learner-content interaction - game, learning discussions (debating) and project.

Among the cooperative teaching methods most effective for forming the cultural competence of future economists, in our opinion, there is a method for analyzing socio-professional problem situations (methods of socioprofessional incidents). Its feature is the use of the "dilemma-based approach", that is, the social and professional dilemma for analyzing and finding ways to solve them.

${ }^{3}$ Hura O.I. (2006) Psychological and pedagogical competence of the higher educational establishment teacher: theoretical and methodological aspect : monograph. Zaporizhzhia : GU "ZIDMU”, 332 p. [in Ukrainian].

${ }^{4}$ Pometun O.I., Pirozhenko L.V. (2004) Modern lesson. Interactive Learning Technologies. Kyiv, ASK Publ. 192 p. 
Here is an example, within a special course "Cultural competence of future economists" on practical classes claimed to analyze and solve such relevant social and professional dilemmas as:

What is it that exceeding power and can give it some higher dignity? It is a component that exceeds power, and we call it authority. Authority is the control we submit to, not just out of sheer (visible or hidden) but through the voluntary recognition. The submission to authority is already a moment of positive appreciation, which is not the case in submitting to mere power.

I do obey power because I cannot disobey it. I can rebel against authority, and if I do obey it because I believe it belongs to me to obey it. So I accept a certain attitude or I obey a certain team that this attitude or this team is expressed by a person I respect, whom I generally believe, whose value I generally recognise. Therefore there is already a moment of voluntariness or will. But on the other hand, there is no true freedom here: I still obey here with someone else's view and someone else's word, taking it to faith as some of the outside given to me. It is impossible not to obey power.

It is worthwhile to obey any word because it is expressed by a person who enjoys my recognition. But even more worthy to obey the same word because I, giving it my consideration, recognized it correct.

Subordination to one's mind and the consistency of one's activities are the highest degrees of subordination or autonomy. Power - authority - mind in the broadest sense of this word, includes science, art and morality - these are the degrees of control and subordination that carry out an increasing degree of freedom and personality. Only a personality, that is, a being who treats himself and those around him critically, can achieve the highest degree of subordination - subordination of the mind as a considerably personal beginning. Subordination of the mind, as the highest form of subordination, does not diminish the importance of authority. Existence, absolutely rejecting authority, would be truly impossible. One can have political views and be critical of the law and the courts, but to reject the authority of the legislator and the courts altogether would be to reject the right itself. It is possible to have own scientific beliefs, but to reject the authority of another scientist altogether, to disregard someone else's word without verifying its correctness would be to make scientific work extremely difficult, to scatter work on trifles, not to get to the most important and essential. Subordination of authority is harmful when authority is the highest authority. However, since in general, the mechanism is useful, as a component of liberty, so far and subordination of authority is useful if it is in the service in the service, which personality ultimately subordinate.

If the directly increased power of authority is the control of authority, then how should we understand the rule of organisation of power we have established: namely, the power which surrounds the child must be organised so that future 
authority can be observed in it? A few well-known examples easily explain this statement. When we demand one thing from children and act differently ourselves, it is obvious that the force with which we force them to do so and not otherwise will be "naked force" for them: if our demands can be violated by elders and even by ourselves, why can't they be violated by children? Only when the teams of elders are steadily obeyed by those around us, when they are not mere orders and words but an objective reality, invariably and always repeated, which can even be imagined differently, as one cannot imagine the nature that surrounds us - the teams will not be something merely due, but a kind of formulation of what exists. This is the basis of the value of example and imitation with the steady precision of the routines of life. If today I forbid something and tomorrow I allow the same if one child is allowed what another is forbidden, then again, the team and prohibitions will be for the child "naked force", the arbitrariness of the strongest - there will be no proper regularity or authority in them. Conversely: authority must be submitted in the form of an immutable natural need. "Allow to accept with pleasure," Rousseau says - refuse versus reluctance. However, let all your refusals be final, let nothing sweat them. Let no, once said, will be solid as iron, which a child, exhausting several times his power, will not continue trying to go in court." The sequence in action includes a sequence in words provided by truthfulness in attitude towards children ${ }^{5}$.

The students in pairs and groups analyzed (following the example of the discussion method) situations in terms of "pros" and "cons" at three levels (aspects) of the problem corresponding to the levels of the social competence functioning: personal (from the position of certain people), educationalprofessional (from the position of social-professional and educationalprofessional interests, economic directions of organizations and enterprises) and the social itself (from the position of the state and society). After that, they can provide possible solutions.

The accent has been made on the fact that in the process of problem situation processing the analysis had general stages of its solution: 1) definition of a problem situation; 2) realization of a problem situation; 3) search for a problem solution; 4) decision-making; prediction of possible consequences and prevention of possible next problems. Observation of work in groups has proved that this specified "movement" contributes to the formation of metacognitive and reflective skills of future economists, motivates their social and professional self-development.

In turn, a method of situational analysis, aimed at forming skills to analyze social information, to make decisions on itself, to design their activities and

${ }^{5}$ Hessen S.I. (1995) Fundamentals of pedagogy: Introduction to the applied philosophy: manual. Moscow : Shkola Press. P. 233. 
development, to predict the process and the result of social, educational and professional interaction. After its development, the decision provided for a meaningful description of the situation at the following stages:

1) preparatory - a clear definition of the situation, the formulation of the goals of its solution;

2) procedural, which contains: analysis of information provided in a content description, searching analogues, preparation of analytical inspection of information; Analysis of strengths and weaknesses (according to SWOT analysis method: strong (Strengths) and weak (Weaknesses) of the situation, opportunities (Opportunities), opened in various ways of developing the situation, and threats (Threats) associated with their implementation); development of scenarios for a possible deployment of the situation (according to the methods of brainstorming, schematization of events, etc.) of the expert forecast of changes in factors and indexes characterizing the situation presented in the form of the most likely scenarios of its development; general assessment of the situation to achieve the goal, generation of decisions; processing data according to various decisions, coordination of thoughts of various experts;

3) final - decision-making and presentation of the decision.

The content of such situations, which were subjected to situational analysis, has been important for the formation of cultural competence of future economists, besides the process of "movement" itself according to the abovementioned stages, providing development of both metacognitive and behavioural and regulatory and reflexive and social interaction skills. They were intended to provide the formation of appropriate social knowledge social awareness and social identity - and to be contextual and socially and personally relevant. Therefore, the situations provided for situational analysis were based on the principle of the influence diversity, i.e. they were aimed at three levels of the social competence functioning: personal, educationalprofessional and social itself.

Here is an example, the students were presented with this situation:

The Pedagogical Council decided to introduce a dress code for students and to introduce fines for violating it (working off socially useful work) because last year the appearance of students has become unacceptable in the opinion of teachers: students come in shorts and flip-flops to classes and exams, students sit in sports uniforms after training and PE in lectures, they wear camouflage clothes, jeans down, in classrooms, they keep their hoods and caps on, female students wear miniskirts and deep necklines. The way out of this situation, from the teachers' point of view, is to introduce a dress code for students.

The students in the groups analysed this situation with the abovementioned stages. In doing so, each group received additional information about the essence and the socially personal meaning of a dress code: 
- dress code (from Eng. - dress code) is an unwritten rule, a regulation in dress indicating a person's belonging to a certain professional or social group; it is a language by which a person sends certain signals to others; it depends on the activity, age, gender, religion, hygiene requirements, etc;

- clothing is a "social marker" of society, providing ready-made behaviour patterns (a leader, an elderly person, a pregnant woman, a clergy member, etc.).

Psychologists have proven that only $7 \%$ of information about a person is verbal information, which is perceived in the first 30 seconds, 30 seconds is an impression of the person with whom we communicate at a subconscious level, $38 \%$ is appearance, $50 \%$ is facial expressions, intonation, gestures; there are different styles of dress - free, business, strict dress code; a dress code is a great potential for those who want to learn to use appearance as an additional tool for communication.

Considering that one of the teaching methods of forming students' cultural competence is the method of social interview, students were given tasks in groups, which consisted in getting a semi-structured interview on a certain topic (for example, "white salary is an advantage for a person, enterprise, country, society", "social responsibility - how I understand it", etc.), which required to develop an interview structure, choose interviewers and present possible employers the economic efficiency of future work. During the training social interview, students learned how to formulate questions, prepared in advance, recorded possible answers, formulated situational questions, and chose the right strategy and tactics to conduct the interview.

Based on the fact that frontal teaching methods involve the entire student body working together to discuss a particular problem and find ways of solving it. Among the most effective methods that can be used to develop cultural competence are the following:

"Microphone" (each applicant has been allowed the opportunity to express his/her opinion on a certain problematic topic or unfinished sentence); such topics are: "in a difficult life situation I ...", "in my opinion, social institutions ...", "in social laws, I am surprised by ...", etc;

"Brainstorming", based on some psychological and pedagogical patterns, involves collective discussion, search for solutions, encouraging participants to interact through free expression of opinions to solve the tasks at hand. Observation of students showed that the use of brainstorming facilitates the development of students' oral speech, communicative and regulatory skills; it encourages them to actively search for the best options to express their views on the task at hand. The prerequisites of the method were adhered to, e. g. limited time for thinking about tasks, the prohibition of criticism, involving all students in the process, recording all ideas and assumptions for further discussion and synthesis; 
"Teaching-to-learn", which involved introducing each other to meaningful information contained in cards prepared in advance by the teacher or by themselves on a particular problematic topic.

For example, information blocks were suggested on such problematic issues as "Cultural identity of modern Ukrainian youth", "Social mobility", "Moral and ethical and professional norms", "Culture of manager's behaviour", etc.;

"Jigsaw", which is based on the interaction of students in two types of groups - home and expert and, accordingly, mastering two types of roles - an equal member of the homegroup who gathers and analyses information and an expert who presents and justifies information at expert level to both other experts and homegroup members.

Here is an example, with this interactive teaching method, students determined the characteristic features of such phenomena as "professional competence", "life competence", "personal competence", "social competence", "civic competence". The student group is united by a random method in four groups (homegroups). Each group received a task using the Venn diagram to determine the common and special characteristics of such phenomena as:

1) professional competence and social competence;

2) life competence and social competence;

3) personal competence and social competence;

4) social competence and civic competence.

After working in "homegroups", the students dispersed to the expert groups, leaving one of them in their homegroup to record the expert opinion. After working in the expert groups, the students returned to their homegroups, made corrections to the diagrams and, after appropriate preparation, presented a group vision of the general and special (specific) characteristics of the above phenomena. The specified method provided, first of all, the formation of such skills as social interaction (possession of means of verbal and nonverbal communication, mechanisms of mutual understanding, ability to work in a team, ability to negotiate, ability to carry out collective creativity) regulatory skills (realization of regulation of own emotional state in situations of social interaction, ability to regulate emotional state in a stress situation, manage own social activity; to assert their position; ability to enter the state of others, to put oneself in the place of another) and reflexive skills (critical analysis of one's actions, deeds, actions and deeds of others, determination of the level of one's social competence, mechanisms of its development). Besides, it provided the actualization of knowledge about the essence of the social competence, its structure and mechanisms of development, reproduction of a situation of various social information reception, the necessity of critical attitude to it (at the reception of false information from an expert group which does not correspond to the information of a homegroup). 
Several interactive game-based methods use business games, role-playing games and imitation games. Their application goal is to train collective thinking and practical work, to form skills and abilities of social interaction, individual and collective decision-making. Students independently chose their role in the game; made an assumption about the probable development of events, created a problem situation, looked for ways of its solution, taking responsibility for the chosen decision. The teacher in the game model acted as an instructor (acquaintance with the rules of the game, consultations during the game), a referee (correction and advice on role distribution), a trainer (hints to students to speed up the game), a presiding officer and a game master (organizer of discussion).

We have noticed that game methods are important for the formation of cultural competence of future economists because they provided not only the successful formation of social, moral and ethical knowledge at all levels but also provided an opportunity to acquire social skills, to practice them in various simulated situations, to master the experience of real social interaction, to try on various social roles, to actualize important personal and professional qualities of students of all groups ${ }^{6}$.

The main feature of game-based methods is the presence of role interaction, which structures the group; the role assigns to each participant of the game a certain position in the group, stipulated by the function. The role in the game is not only the sum of functions, but also of patterns of behaviour, and the participants in the game form a certain system of expectations regarding the bearer of a certain role.

In terms of structure, the game class consisted of four stages: orientation (introduction of the students to the topic, familiarisation with the rules of the game, general overview of its flow), preparation for the game (familiarisation with the game scenario, the definition of game tasks, roles, oriented ways to solve the problem); the main part - conducting the game; discussion of the result ${ }^{1}$.

During class, students adhered to the basic requirements for games to form the social competence of future economists. Such requirements, in our opinion, are $^{7}$ :

- distribution of roles between the participants in the game according to the degree of sociality;

- joint activity of the participants in the game in conditions of differentiation and integration of functions are simulated;

${ }^{6}$ Romanyk A. (2004) The role of student self-government in Ukraine and countries of Western Europe. Student's self-government in Ukraine. Kyiv : "Molodizhna al'ternatyva", pp. 6-10 [in Ukrainian].

${ }^{7}$ Ibid. 
- cooperation of the participants in the game under conditions of differentiation and integration of functions, simulated;

- dialogue between partners as a condition for making joint decisions;

- presence of a common game goal for the whole game group (game system), which is the background for the deployment of social and educational-professional conflicts and contradictions;

- flexible time scale;

- introducing improvisations (contingencies that simulate possible unpredictable social processes) into the game;

- usage of a system of assessment of game performance and professional knowledge to ensure competitiveness;

- presence of a system of social and other incentives that motivate the reproduction of established social skills in real-life situations;

- dynamism, continuity and emotionality;

- focus on the formation of social awareness, social identity and social experience of students.

\section{The most effective interactive teaching methods in building the cultural competence of future economists}

The most effective interactive teaching method used in the study has become a teaching discussion that is a way to organize joint activities that contributes to the development of a common solution to a problem; by learning, which increases the effectiveness of the educational process due to public discussion of an important issue, exchange of views, including students in a collective search of the truth. The most effective discussion has been found in the classes of economic disciplines since it develops independent thinking, the ability to argue own opinion, analyze and confirm or deny the statement, critically assess the information received.

Scientific conclusions and data requiring additional training on sources that contain more detailed information than the textbook have been discussed during the teaching discussion.

Note that structurally the discussion consists of three stages - orientation (familiarisation of participants with the discussion problem, formulation of objectives, setting of rules and regulations), assessment (presentation of participants, discussion, answers to questions) and consolidation (analysis of results, agreement of opinions and assumptions, formulation of conclusions, summing up and decision-making).

In the experimental activity, the advantages of discussion were confirmed because it is aimed at both learning new knowledge and creating an emotionally rich atmosphere, which contributed to deep penetration into the truth.

One of the innovative interactive technologies of teaching students and pupils, forms of learning discussions, which is an effective means of the formation of cultural competence of future economists is a debate. 
Debating technology is defined today by scientists and practitioners as the most effective in the aspect of the formation of their civic competence, development of critical thinking and communicative skills is debating technology (A. Yermolenko ${ }^{8}$, O.V. Zyma ${ }^{9}$, N. Claxton, A. Crawford, O.I. Pometun ${ }^{10}$, A. Schneider, etc.). Despite somewhat different approaches of scholars to the categorical definition of the essence of debate in pedagogical research, in particular in their attribution to special pedagogical methods (A. Crawford, A. Schneider, M. Schnurer, etc.), teaching strategies (S. Scott, D. Steinberg, A. Frilli, etc.) or a separate pedagogical technology (S. Imzharova, O. Pometun, etc.), it is debate as a special educational tool that has great potential to ensure successful professional learning and professional development of future specialists.

Following O.I. Pometun, debates (from French) is understood as a special pedagogical technology that consists of a specially organized, clearly structured public discussion on a topical issue, aimed at developing (development of cognitive, emotional-volitional, communicative, organizational and managerial, moral qualities of a personality), didactic (formation and actualization of knowledge, its transformation into a personal form, formation of learning, self-educational abilities and skills) and socialization (mastering social roles and norms, forms of education).

Considering the debate as a pedagogical technology that is being implemented in the educational process, we note that they relate to academic can be conducted in the following common forms in the direction of the number of participants, the presence of time-outs and others.

Various forms of academic debate based on the same principles have been taken into account in implementing the model. Let us elaborate in more detail. These are the principles of:

1) educational orientation - orientation on the formation, updating of knowledge, mastering participants with new educational and professional skills, development of personal and professional qualities; 2) taking into account the age and individual psychological characteristics of participants - students; 3 ) humanistic orientation - recognition of unconditional value, the capacity for self-development and self-education, competence, the activity of each participant, respect for opponents, tolerant attitude; 4) partner communication of organizers and participants; 5) contextual approach - actualization of

\footnotetext{
${ }^{8}$ Yermolenko A. B. (2015). Debate Technologies: Pedagogical Practice. Postgraduate education in Ukraine. № 1 (36), pp. 81-85.

${ }^{9}$ Zyma O.V. (2013). The concept of "debate" in scientific literature, their application at the lessons of social science subjects. URL: https://www.narodnaosvita.kiev.ua/ Narodna_osvita/vupysku/18/statti/zima.htm

${ }^{10}$ Ibid.
} 
students' future professional activity in their learning activity; 6) game modeling - construction of debate scenario according to business game requirements; 7) integration - selection of debate topics considering integration of educational and professional content, interdisciplinary context; 8) reflection obligatory conducting of reflection procedures, activation of participants' reflexive skills. The important structural elements of academic debates were adhered to during interaction. These are the subject of the discussion (the resolution, the arguments of the opponents, the cases of the parties), the subjects of the discussion (the participants in the debate in various functional roles), the activity space (the organisation of the communicative situation) and the activity time (the duration of speeches, the presence of time-outs).

Within the special course "Cultural competence of future economists" conducted a debate on the "Socio-cultural competent behaviour of modern economist", "Cultural identity of a young person", "Projected socioprofessional development of a student." Each of the debate has been built on the following program:

Introduction (peculiarities of debating; tips on how to build a successful presentation using video speeches by today's most successful speakers, including N. Vujicic, etc.);

Preparation for the debate (announcement of the problem to support or deny, division of participants into teams: the "Judges" team: 3 qualified experts (chairman, technical secretary, expert) the "Confirmation" team: 3 speakers, 3 assistant speakers; the "Objection" team: 3 speakers, 3 assistant speakers; the "Timekeepers" team: 2 members; announcement of tasks to the teams:

- the "Confirmation" team's task: the team has to define the topic, i. e. define its meaning. The confirmation team should define the topic as a normal person would. The assertion speaker does not have to define every word of the topic, but to be able to explain the meaning of the topic and why it is needed;

- the "Objection" team's task: to argue with the confirmation team's case. The objection team can only question the definition of the topic if they feel that the definitions of the topic are unfair to them. Definitions, which are inconsistent with the topic, can be unfair, too specific or make the team's case uncontroversial. The objection team can refute any parts of the case statement and present its case.

Debating according to the following scheme:

The first speaker of the "Confirmation" team (should announce the concepts of the topic (definitions, criteria) and present a case (arguments, main ideas) assertion that supports the topic. The rest of the team members can repeat his ideas, expand on them, but no new arguments are allowed (except from the objection team), the question of the third "Objection" team speaker to the first "Confirmation" team speaker; 
The speech of the second "Confirmation" team speaker (two tasks - 1) to refute all the arguments of the objection team; to refute all the arguments of the objection team. If the arguments of the "Objection" team do not refute, they can be considered as agreed.

The second speaker of the confirmation team has to extend his arguments with new supporting material - the question of the first "Objection" team speaker to the second of the "Confirmation" team speaker;

The speech of the second "Objection" team speaker (two tasks: to continue refuting the approval case and answer the refuting of his team case. The second "Objection" team speaker should also expand the arguments of his team - the question of the first "Confirmation" team speaker to the first "Objection" team speaker;

The speech of the second "Objection" team speaker (two tasks: the speech of the third "Confirmation" team speaker (the task is to summarise the debate and show the judge why his team has won. If the speaker in his/her speech uses new ideas, facts, evidence or arguments that were not in the speeches of the previous speakers, the judge does not take them into account and can reduce the speaker-points of the participant;

The speech of the third "Objection" team speaker (the task is to summarise the debate and show the judges why his team has won).

Judges' assessment (based on the assessment sheets).

Summing up the results. Announcement of the winners.

Our monitoring has shown that innovative, interactive teaching methods such as project-based teaching methods are important for shaping the cultural competence of future economists.

In general, the term "project" has several meanings: 1) it is a preliminary (allowable text of any document) 2) it is a certain action, a set of activities united by one programme, or an organisational form of purposeful activity (like projection, project activity); 3 ) it is an activity to create (develop, plan, construct) some system, object, model. Educational project management, as S.U. Honcharenko ${ }^{11}$ has noted, is aimed at creating models of planned (future) processes and phenomena (as opposed to modelling, which can be extended to experience to comprehend it more deeply).

In the pedagogical science of the XXI century, the projection as a special educational method of scientists is considered in different ways, in particular as a means of achieving the didactic goal due to the detailed development of a problem that should end with a real, tangible practical result, executed in one way or another way (E.S. Polat); the creative work of students within a

${ }^{11}$ Honcharenko S.U. Pedagogical research: Methodological advice to young scientists. Kyiv-Vinnytsia, Ukraina: DOV "Vinnytsia". Kyiv-Vinnytsia : DOV "Vinnytsia", 278 p. 
given theme that has an integrated character (V.N. Sternberg); the special system of teaching, according to which students acquire knowledge in the process of planning and implementing gradually complicated practical tasks - projects (H.M. Kodzaspirova,), etc.

Because the projection is a special human activity aimed at creating an image, a model of any object/phenomenon or process, the project method is a special pedagogical means of developing professional competence of future specialists in the process of their independent creation and implementation of projects to solve a certain problem of professional education ${ }^{12}$.

Leaving aside the debate on the project management as a method or technology, we note that its basic attributes are:

- the existence of a socially/professionally/personally significant problem that determines the topic of the project; a specific addressee - the project customer;

- the independent, individual nature of students' activities;

- the meta disciplinary nature of the project;

- the structure of the work, the presence of a specific projection technology;

- the application of research, search methods for solving creative problems.

During the project activities, the methodological foundations of the project management in education (I.A. Kolesnikov, etc.) are taken into account:

- the anticipation, perspective approaches, embedded in the word "project" itself - a throw into the future;

- the potential difference approach - between the actual state of the subject/process and the desired one;

- the step-by-step approach - the gradual approach of the desired future image;

- the compatibility, cooperation, pooling of resources approaches and efforts in the projection;

- the extended activity of participants approach in the process of joint action (by W.H. Kilpatrick).

The basic principles of the projection in higher education to ensure its effectiveness are taken into account. These include predictability (aiming at a future desired result) innovativeness (lack of analogue) meticulous (manufacturability, availability of an action program); rationing (need to pass stages within regulated procedures) feedback (constant reflection of activity and its intermediate outcomes); pragmatism (performance, obligatory focus

${ }^{12}$ Kolyadenko S.V. (2016) Digital economy: preconditions and stages of formation in Ukraine and in the world. № 6, pp. 106-107. 
on the applied result) cultural analogy (adequacy of the projection results to a certain cultural environment); and the ability of the projection to be effective.

Following the basic requirements for the projection in higher education that ensure its effectiveness, in our opinion, there is the social and personal significance of the problem that requires solving integrated professional and research tasks; the practical professional, theoretical, cognitive significance of the expected results; the combination of different forms of individual, group and teamwork of students; step-by-step structuring of work according to the general structure of activity and stages of thinking and decision-making activity (development of project task, project implementation, registration of results; project presentation and defence, general reflection) usage of different research methods; organization of educational space according to all requirements of training environment; thorough preparation of teachers, etc.

In general, the projection as a method of professional training of future specialists in higher education has been implemented in the following stages that determine and preparing a teacher, namely:

1) organizational and preparatory, which involves awareness of a student situation, methodological processing of information and wording of the project task, creation of graphic pre-project analysis in the form of a scheme; 2) searching, the content of which is to nominate the hypothesis, the search for ways to solve the problem, search, produce and create sketch ideas, schemes/models of the project solution; 3 ) solving that ensures the creation of a project program, its analysis and implementation, creating a holistic project solution; and 4) reflexive, which involves analysing the relevance of the objective and the project solution, making adjustments, carrying out additional research, and the presentation of the solution itself, which can take the form of a separate educational event inviting employers, specialists and the public.

Based on the general typology of projects in higher education, the following were considered during the formative experiment: 1) according to the dominant activities - research, search, creative, role-playing, application, orientation, information projects; 2) by subject-matter area - mono projects (within a single field of knowledge) and interdisciplinary and metadisciplinary projects; 3 ) by the nature of project coordination - direct (rigid, flexible) and implicit (implicit, imitating participants); 4) according to the nature of the participants' contacts - from the same group on different grounds (intra-university, student) and inter-group (inter-university, mixed); 5) according to duration - mini-projects (one study unit), short-term, long-term.

The general criteria has been taken into account when assessing the results of the implementation of the project method in higher education, according to the D. Kirkpatrick Model (levels of reaction, learning, behaviour and outcome), which are: 1) the satisfaction with participation in the project 
(positive impressions, participants' willingness to continue work); 2) the extent to which the participants have mastered the projection procedures (at the level of knowledge and skills in problem-solving, goal-setting, anticipation, decision-making, reflection, presentation of results, etc.); 3 ) the quality of the project result as a whole - its social significance, creativity and innovation; 4) the positive shifts in the personal level of participants (dynamics of personal and professional qualities); 5) the synergy effect - the appearance of a project team; 6) the establishment of social partnerships - building social ties between professionals, students and partners.

In our opinion, the basic condition for successful implementation of the projection as a means of developing professional competence of future specialists in higher education is special training of teachers who are proficient in game, activity, reflexive, problem-based learning methods, and can be active members of the project team. It is important to involve specialists from different spheres of activity to participate in students' project work, ensures its meta disciplinary, applied, professionally significant character.

In our opinion, the feasibility of applying the project method to develop the cultural competence of future economists is justified by the following provisions:

- projection is a universal, meta-disciplinary type of human activity, carried out by the stages of solving any problem situation, and then provides the formation of socio-professional knowledge of future economics students at all its levels, as well as metacognitive skills;

- group work on a socially significant problem: provides activation of social motives of the behaviour of future specialists, the motivation of their social and professional self-development; contributes to overcoming social stereotypes, attitudes;

- correctly structured process of student interaction in group work ensures that students' interest in social interaction and communication and desire for social interaction is intensified;

- passing all the stages of the projection ensures the formation of cultural competent behaviour of students.

In the process of forming cultural competence of future economists, both separate project methods in the disciplines of humanitarian and general economic training, and as an independent educational activity - socio-cultural youth projects - have been used.

Thus, during 2019-2020, socio-cultural youth projects have been organised and implemented that goal to shape the cultural competence of applicants for economic professions:

- "Student Initiative Center", which provides for the development and presentation of projects aimed at sustainable development of the city and the 
region in such areas as industry; economy and entrepreneurship; agriculture; education, science, culture; health care; sports, tourism;

- Housing and communal services; nature management; social services; youth policy, patriotism, volunteerism, civil position;

- "Kherson Vector of Student Initiatives", which also envisaged the development and presentation of projects aimed at sustainable development of the city of Kherson and Kherson oblast in such areas as:

- green tourism of the Kherson region (to offer new ideas and projects and mechanisms for their implementation in practice);

- cultural and entertainment infrastructure of Kherson (to diversify and suggest for implementation the best know-how from the world cities experience);

- improvement of the environmental situation and quality of life standards of Kherson residents (to suggest mechanisms for solving specific environmental problems and long-term social programmes).

\section{CONCLUSIONS}

Organizational and pedagogical conditions that ensure the effectiveness of formation of cultural competence of future economists are determined by 1) updating the content of humanities and general economic cycle disciplines based on meta-disciplinary approach; 2) cross-curricular implementation of interactive teaching methods in the classroom and extracurricular activities of future economists; 3 ) creation of an enriched socio-professional environment. Each of the organisational and pedagogical conditions is ensured by a complex of various forms and methods of teaching and is implemented by the logical unfolding of the founding and motivational, content-operational and controlreflexive stages. The criteria for the formation of cultural competence of future-student economists have been defined as 1) social identity as a result of the development of its value component; 2) social awareness as a result of the development of its cognitive component; 3 ) socially competent behaviour as a result of the development of its constructive component. Each of the criteria has specific and diagnostic indicators, appearing at three levels: low (initial), medium and high.

The application of interactive teaching methods in the teaching of future economic specialists contributes to better and more effective preparation for the activities of specialists, forms the abilities and skills that are necessary to solve complex problems in professional activity, the development of critical thinking and personality formation.

\section{SUMMARY}

At the present stage of development of Ukrainian society, the problem of forming cultural competence of future economists in the process of training 
becomes particularly acute because it determines the ability of a specialist to work in a team, to interact effectively in the digital society, to achieve the goals, to make decisions, to project their own social, personal and professional growth, to respond constructively to stress, etc. The article analyses cultural competence as an integral quality of a personality, which manifests itself in the general ability and capacity of a person to diverse activities, socially orientates a personality to independent and successful life activity. The assessment of cultural competence is based on a set of pedagogical approaches - normative, competence-based, personal, and technological.

The conclusions point out that the principles of cultural competence assessment are integrity, dynamism, continuity, informativeness, cyclicality, consistency, effectiveness. The main directions of assessment are defined as the activity to identify a) competences related to a person as an individual, subject of activity and communication; b) competences related to the social interaction of a person and social environment; c) competences related to a person's activity.

\section{REFERENCES}

1. Varnavska, I.V. (2021) The value of cultural competence in the professional activity of a manager. Integration of Education, Science and Business in Modern Environment: Winter Debates: abstracts of the 2nd International Scientific and Practical Internet Conference, February 4-5, 2021. Dnipro, Ukraine, 2021. P. 1. P. 233-235.

2. Hessen S.I. (1995) Osnovy pedagogiki. Vvedenie v prikladnuyu filosofiyu. [Fundamentals of pedagogy: Introduction to the applied philosophy: manual]. Moscow : School-Press, $448 \mathrm{p}$.

3. Honcharenko S.U. (2008) Pedagogical research: Methodological advice to young scientists. Kyiv-Vinnytsia, Ukraina: DOV "Vinnytsia" [Pedahohichni doslidzhennya: metodolohichni porady molodym naukovtsyam]. Kyiv-Vinnytsia : DOV "Vinnytsia", 278 p.

4. Hura O. I. (2006). Psykholoho-pedahohichna kompetentnist' vykladacha vyschoho navchal'noho zakladu: teoretyko-metodolohichnyj aspekt]: monohrafiia [Psychological and pedagogical competency. The main responsibility of the main mortgage: theoretical and methodological aspect]. Zaporizhzhia, Ukraine : HU "ZIDMU" [in Ukrainian].

5. Yermolenko, A. B. (2015). Debatni tekhnolohii: pedahohichna praktyka. Pisliadyplomna osvita v Ukraini. [Debate technology: pedagogical practice]. № 1 (36), pp. 81-85.

6. Zyma, O. V. (2013). Ponyattya "debati" u naukoviy literaturi, ikh zastosuvannya na urokakh suspilstvoznavchikh predmetiv. [The concept of "debate" in scientific literature, their application at the lessons of social science subjects]. URL: https://www.narodnaosvita.kiev.ua/Narodna_ osvita/vupysku/18/statti/zima.htm [in Ukrainian]. 
7. Kolyadenko, S.V. (2016), Digital economy: preconditions and stages of formation in Ukraine and in the world. [Tsyfrova ekonomika peredumovy ta etapy sanovlennia v ukraini ta sviti. Ekonomika. Finansy. Menedzhement]. № 6, pp. 106-107.

8. Komar, O. A. Interaktivni tehnologiyi u vischih navchalnih zakladah. [Interactive technologies in Higher Studying Institutions]. URL: http://dspace.udpu.org.ua:8080/jspui/bitstream/6789/375/1/interaktuvni_tehn _vnz.pdf

9. Pometun, O.I., Pirozhenko, L.V. (2002). Interaktivni tehnologiyi navchannya: teoriya, praktika, dosvid: [metodychnyi posibnyk]. [Interactive technologies of teaching: theory, practice, experience]. Kyiv. 237 p. [in Ukrainian].

10. Pometun, O.I., Pyrozhenko, L.V. (2004). Suchasnyi urok. Interaktyvni tekhnolohii navchannia: nauk. - metod. posibnyk. [Modern Contemporary Lesson: Interactive Learning Technologies]. Kyiv : Vydavnytstvo A.S.K., $192 \mathrm{p}$.

11. Romanyk, A. (2004). Rol studentskoho samovriaduvannia v Ukraini ta $\mathrm{v}$ krainakh Zakhidnoi Yevropy [The role of student self-government in Ukraine and in countries of Western Europe. Student's self-government in Ukraine]. Studentske samovriaduvannia v Ukraini. Kyiv: "Molodizhna alternatyva", pp. 6-10 [in Ukrainian].

\section{Information about the author: Varnavska Inna Viacheslavivna,}

Candidate of Pedagogical Sciences, Associate Professor, Associate Professor at the Department of Professional Education Kherson state Agrarian and economic University

23, Stritenska st., Kherson, Ukraine, 73006 orcid.org/0000-0002-3061-0665 